\title{
Domestic violence: repercussions for women and children
}

\author{
Violência conjugal: repercussões para mulheres e filhas(os) \\ Violencia de pareja: repercusiones para mujeres y niñas(os)
}

Jordana Brock Carneiro ${ }^{1}$ Nadirlene Pereira Gomes ${ }^{1}$ Fernanda Matheus Estrela ${ }^{1}$ Jéssica Damasceno de Santana ${ }^{1}$

Rosana Santos Mota ${ }^{1}$

Alacoque Lorenzini Erdmann²

1. Universidade Federal da Bahia.

Salvador, BA, Brazil.

2. Universidade Federal de Santa Catarina.

Florianópolis, SC, Brazil.
Corresponding author:

Jordana Brock Carneiro.

E-mail: jordanabrock@yahoo.com.br

Submitted on $12 / 03 / 2016$.

Accepted on 04/13/2017.

DOI: 10.1590/2177-9465-EAN-2016-0346

\begin{abstract}
Objectives: To know the meanings attributed by women regarding the repercussions of the experience of domestic violence. Method: Qualitative study, based on the Grounded Theory method. Data were collected in two sticks of domestic and family violence against the Brazilian Northeast woman. An interview was conducted with 37 participants, who composed two sample groups. Results: The study demonstrates that the physical and mental health of women and their children are compromised, expressed through visible marks such as bruises and cuts, in addition to low self-esteem, sadness, fear and depression. There are also repercussions for the social relations of women as a consequence of social isolation and non-qualification for the labor market, and of children, related to the decrease in school performance, introspection and vulnerability to drug use. Conclusion: It is necessary to sensitize health professionals to the recognition of cases and promote educational actions, thus transcending the invisibility barrier of domestic violence.
\end{abstract}

Keywords: Violence against Women; Family Conflict; Public Health.

\section{Resumo}

Objetivo: Conhecer os significados atribuídos por mulheres acerca das repercussões da vivência de violência conjugal. Método: Estudo qualitativo, apoiado no método da Grounded Theory. Os dados foram coletados em duas varas de violência doméstica e familiar contra a mulher do nordeste brasileiro. Realizou-se entrevista com 37 participantes, que compuseram dois grupos amostrais. Resultado: O estudo aponta comprometimento para a saúde física e mental das mulheres e seus filhos, expressa por marcas visíveis, como hematomas e cortes, além de baixa autoestima, tristeza, medo e depressão. Revelam-se ainda repercussões para as relações sociais das mulheres, por consequência do isolamento social e da não-qualificação para o mercado de trabalho, e das crianças, relacionadas à diminuição no rendimento escolar, introspecção e vulnerabilidade para o uso de drogas. Conclusão: Faz-se necessário sensibilizar profissionais de saúde para o reconhecimento dos casos e promover ações de educação, transcendendo, assim, a barreira da invisibilidade da violência conjugal.

Palavras-chave: Violência Contra a Mulher; Conflito Familiar; Saúde Pública.

\section{Resumen}

Objetivo: Conocer los significados asignados por mujeres sobre el impacto de las experiencias de violencia de parejas. Método: Estudio cualitativo, apoyado en el método de la Grounded Theory. Los datos fueron colectados en dos varas de violencia doméstica y familiar contra la mujer del nordeste brasileño. Se realizó una entrevista con 37 participantes, que compuesto por dos grupos de la muestra. Resultado: El estudio muestra comprometimiento para la salud física y mental de las mujeres y sus hijos, expresa por marcas visibles, como hematomas y cortes, además de la baja autoestima, tristeza, miedo y depresión. Se revelan más repercusiones para las relaciones sociales de las mujeres, por consecuencia del aislamiento social y de la no-calificación para el mercado de trabajo, y de los niños(as), relacionados a la disminución en el rendimiento escolar, introspección y vulnerabilidad para el uso de drogas. Conclusión: Es necesario sensibilizar profesionales de la salud para el reconocimiento de los casos y promover acciones de educación, transcendente, así, la barrera de la invisibilidad de la violencia de parejas.

Palabras clave: Violencia Contra la Mujer; Conflicto Familiar; Salud Pública. 


\section{INTRODUCTION}

The marital violence perpetrated against women is considered a public health problem in Brazil and in different parts of the world. In 2014, the Call Center for Assisting Women provided by the Presidency of Republic (Call 180) made 52,957 calls relating to violence against women. This number represents more than 145 complaints per day. ${ }^{1}$ Among the women who used this center to report marital violence, $43 \%$ reported daily aggression and $35 \%$ weekly. ${ }^{1}$ Therefore, it can be seen that although violence is considered a crime and violation of human rights in Brazil, this fact does not prevent many women from being routinely victimized.

International studies also reveal the high number of cases of violence against women. The US Department of Health and Human Services estimates that more than five million women are raped by their partners or ex-partners each year in that country. ${ }^{2}$ In Canada, in 2011, marital violence accounted for approximately $25 \%$ of all violent crimes reported to the police. ${ }^{3}$ In the UK, 4.6 million women aged 16 or over have already been victims of domestic violence. ${ }^{4}$

In Brazil, according to Law 11,340/2006, these aggressions can be expressed in patrimonial, moral, psychological, sexual and physical forms. ${ }^{5}$ In the United States and Wales, moral violence is understood as psychological violence, and the other forms resemble the classification advocated by the Maria da Penha Law in Brazil. ${ }^{2,4}$ Regardless of the form of expression, the experience of domestic violence compromises the health and quality of life not only of women, but of the family as a whole. In view of the above, the following questions arise: what are the meanings attributed by women in legal proceedings regarding the repercussions of domestic violence for themselves and their children? The aim was to know the meanings attributed by women to the repercussions of the domestic violence experience.

\section{METHODS}

This is a qualitative research, master dissertation cut, linked to the matrix project "Re-education of men and women involved in criminal prosecution: a strategy for confronting marital violence", funded by the Foundation for Research Support of the State of Bahia and supported by the Public Security Secretariat of the state of Bahia. In this study, the Data Based Theory (DBT) or Grounded Theory was adopted as methodological reference. This theory seeks to understand the meaning of the relationships and interactions between social phenomena in the reality in which they are inserted. ${ }^{7}$

The scenario chosen for the study was two courts of domestic and family violence against women, located in the state of Bahia, Brazil. There was an individual, semi-structured interview guided by the question: "What repercussions has the experience of domestic violence unleashed in your life?"

New questions were addressed by the researchers based on the participants' answers. Following the assumptions of the DBT, the insertion of participant occurred respecting the principles of theoretical sampling. Thus, the first sample group consisted of 29 women who experienced marital violence and met the following inclusion criterion: being involved in a lawsuit with the domestic and family violence against women, whose representation was due to domestic violence. Women whose psychological state made their participation contraindicated by the psychosocial service of the staff were excluded from the study. After identifying the possible participants of the study, they were invited by the social service of the staff to participate in the research through an interview, which took place in a previously scheduled location at the Federal University of Bahia. The analysis of the data was performed concomitantly to the collection, allowing the discovery of codes and categories.

The procedural analysis of the data enabled the construction of hypotheses that directed the need to hear representatives of institutions of the Network to Combat Violence against Women mentioned in the interviews. We interviewed eight professionals in the second sample group: one social worker, one psychologist, one conciliator, two public defenders, two prosecutors and two magistrates. Together, the two sample groups totaled 37 participants. Data collection was performed from November 2014 to May 2015. The statements were recorded on a portable recorder, transcribed in full and their data encoded with the support of the NVIVO $10^{\circledR}$ organizer software.

The DBT provides open, axial and selective coding in its analysis process, which is performed by comparing the data until it reaches the study phenomenon. ${ }^{6}$ The process begins with open coding, in which the researcher begins to analyze, line by line and free form, the data. From the open coding the substantive codes are generated and then, with the axial coding, these codes are regrouped and interrelated, favoring the emersion of the theoretical codes. During this coding stage, the categories and subcategories were organized into the five components of the paradigm model: context, causal condition, intervening condition, strategy and consequence. Finally, in the selective coding, all categories and subcategories were constantly compared and analyzed to constitute the category or central phenomenon. ${ }^{6}$

The development of the study met the ethical aspects recommended in Resolution 466/12 of the National Health Council, and the project was submitted and approved by the Research Ethics Committee of the Federal University of Bahia (opinion No. 039699/2014). The consent of the participants was obtained through the signing of the Informed Consent Term. In order to preserve the anonymity of the participants, the women in court were coded with flower names followed by their age and the professionals of the institutions were identified with the letter " $\mathrm{P}$ " followed by an Arabic numeral of the interview order (P1, P2,...).

\section{RESULTS}

The use of the paradigmatic model allowed the construction of a theoretical matrix explaining the phenomena studied (Figure 1), being validated by researchers with experience in PDT and by the research participants. 
Figure 1. Theorical Model of Substantive Theory.

Source: Field survey. Semi-structured interview conducted with women experiencing marital violence between November 2014 and May 2015. Domestic violence: providing meaning to expressions and repercussions from the Grounded Theory perspective Salvador-BA, 2016.

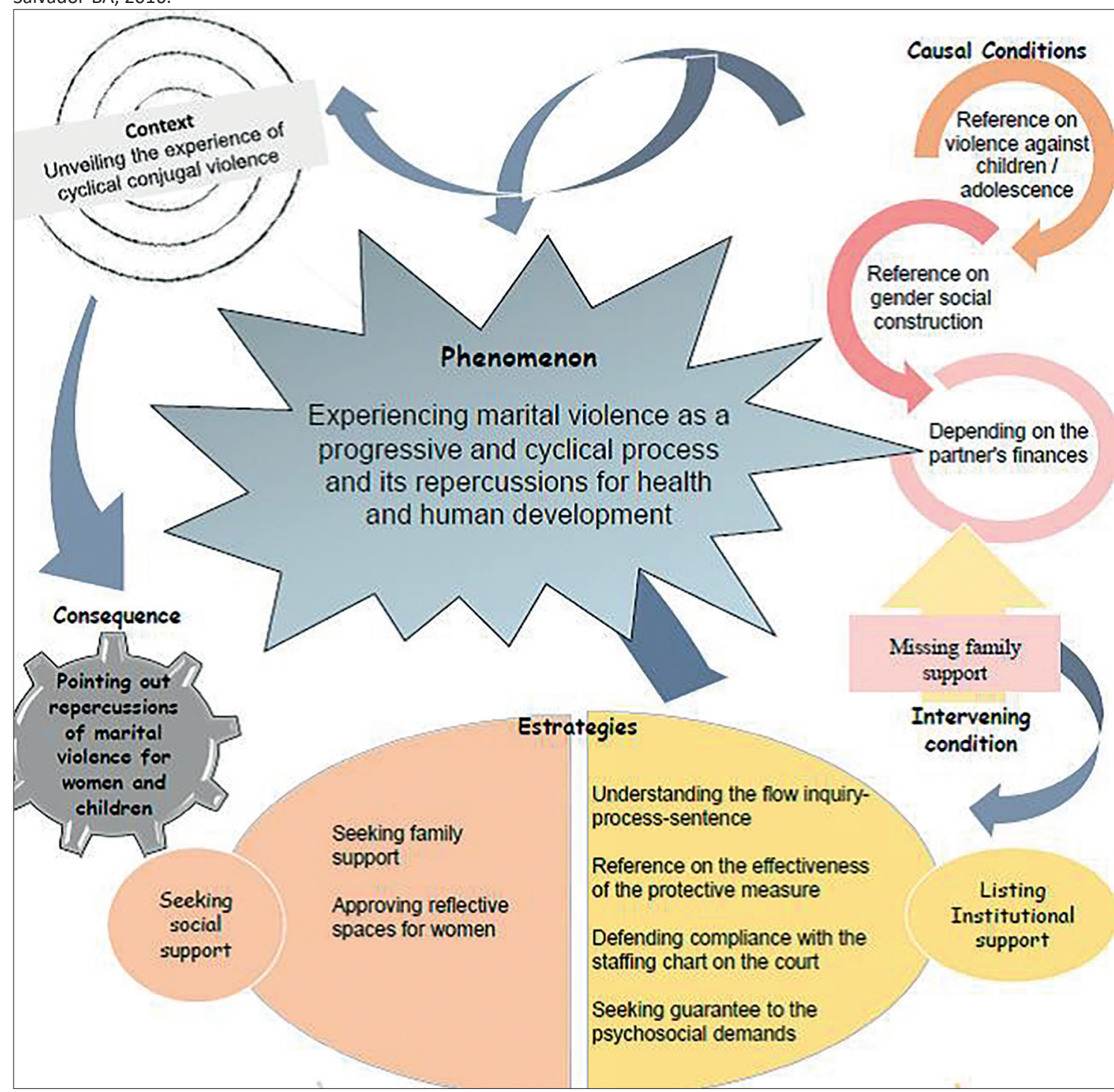

In this study, the categories referring to the consequences that are articulated to the phenomenon revealed in the codification process will be presented and discussed: "Experiencing domestic violence as a progressive and cyclical process and how it affects health and human development." The validation of the paradigmatic model, also called theoretical matrix, was carried out by researchers with experience in DBT and by research collaborators.

The result of the study points to the biopsychosocial dimension of domestic violence, considering the repercussions on the physical and mental health of women and the commitment to human development. It also adds to the vulnerability of children to mental illness, drug use and decreased school performance.

\section{Reference to the repercussions for women}

\section{Reference to damage to physical health}

Experiencing violence in domesticity leads to damages on the physical health of women. These damages range from visible marks resulting from physical aggression to more veiled situations such as the acquisition of sexually transmitted infections, as a result of asymmetrical gender relations, and clinical symptoms, triggered by the somatization process of violence experienced.

[...] He beat me a lot, especially in the face to make me look ugly. [...] he would strike and my eye would get swollen and bruised. [...] once, he broke my chin. (Mouth dandelion flower, 49 years old) 
He hit my face, my eye turned red with blood and I got dizzy and nauseated. [...] He didn't want to use a condom. I got syphilis and was hospitalized for 14 days for treatment. (Jasmine, 71 years)

I was very sad, I lost weight. [...] my blood pressure was high. [...] the doctor said it was stress. (Camellia Sasanqua, 37 years old)

\section{Uncovering the compromize of mental health}

The speeches reveal the psychological suffering of women, characterized by fear, repulsion, deep sadness, low self-esteem and other symptoms of depression, as shown in the following lines:

I lost my identity, my self-esteem, my confidence, my personality. [...] I felt coerced, oppressed, embittered, trapped. (Chrysanthemum, 31 years old)

[...]l slept with a knife under the pillow for fear. [...] I felt like a useless, horrible person, a wreck, horrible, incompetent, incapable. [...] he did not have the courage to get out of bed without a desire to live. I had panic syndrome. I have no plans for life. I lost that glitter I had! (Tulipa, 29 years old)

We realize that violent relationships undermine women's self-esteem. [...] they cry a lot. We perceive frailty and fear. [...] many suffer from depression, insomnia, and a sense of dread. (P7)

\section{Signaling implications in terms of social relations}

The human development of women is compromised since, when they feel oppressed, they present difficulties for social interaction. The speeches show such difficulty and signal to a movement in search of greater sociability:

He wouldn't let me be in contact with my family or even have friends. [...] It's been 18 since I last traveled to see my people. (Freesia, 37 years old)

I became very closed and quiet, even at work. I would finish work without talking to anyone through the day. He did not like me talking to anyone, but now I'm trying to interact with other people: I go out with friends; I go to relatives' house. I'm more open to talk, to laugh. (Daisy, 38 years old)

I'm better than before: I leave, I go everywhere. [...] I am no longer oppressed. Now l just want to live, to go out, to live with my friends, with my family. (Jasmine, 71 years old)

Marital violence also compromises the development of potentialities to ensure women provide for their own subsistence. This is because throughout their married life, they devoted themselves exclusively to domestic demands, not qualifying themselves for the labor market. The following statements express concern in terms of their entering the labor market:
I went to college, but I've never worked. I just looked after the house, the girls and him. [...] I couldn't find a job.. (Orchid, 43 years old)

I have to pay rent, school expenses, day care and transportation. It's hard for me because he would not let me work when we were married. [...] I need an opportunity: get a better job. If I have the opportunity I would like to go to college. (Sunflower, 32 years old)

I follow several situations in which the aggressor seeks to make it difficult for women to enter the labor market. [...] Normally, they are women who are economically dependent on the spouse. So they end up silencing. (P8)

\section{Reference in terms of the repercussions for children}

Children of parents experiencing marital violence are more susceptible to violence, as the following statements illustrate:

My daughter got into an argument; He pushed her and she almost hit her head. (Margarida, 38 years old)

He cursed and beat my daughters; he called them disgrace. He said he didn't want them. (Calendula, 38 years old)

[...]she was having a fight with her partner. The son got in and he cut the boy's hand with a knife. (P5)

The study also indicates that exposure to situations of domestic violence compromises the mental health of children; it makes them vulnerable to drug use and interferes with school performance.

My six-year-old son had depression. I know l've harmed him. (Glass of Milk, 57 years old)

[...] My children started using drugs. (Jasmine, 71 years old)

[...] My eldest son has become an alcoholic, and the younger one has a very strong depression. (Gardenia, 39 years old)

My son got depressed: very quiet and introspective. He was afraid, upset and more aggressive. His school performance has decreased. (Tulipa, 29 years old)

Children become psychologically shaken. [...] this influences school performance. (P7)

\section{DISCUSSION}

The study reveals that the experience of physical violence in the marital relationship leaves marks on the bodies of women, such as bruising. In the international scenario, a survey conducted in Italy with 6,936 women points to strains as the main harm of marital violence, ${ }^{8}$ which can trigger bruising most of the time. Damage to physical integrity is corroborated by the 
national literature, such as a study with victims of aggression, which also cites: bruises, cuts, lacerations, sprains and fractures, according to a study based on the analysis of 1,965 medical records of women treated in the Instituo Médico Legal (IML Forensic Institute). ${ }^{9}$

The aggression in the face reported in the study was also identified in a study carried out in Brazil that points the face as the place most commonly affected by physical violence. ${ }^{9}$ Physical violence at the face is considered a symbol of humiliation. It is believed that spouses purposely choose the face in order to make visible the power they believe they have over their partners. ${ }^{10}$ The belief of male supremacy is anchored in the patriarchal model, according to which men hold the power of family, children, and woman. These asymmetrical relations place women in a subservient position in relation to men.

In a marital relationship anchored in gender inequality, women abide by the spouses' desire and/or impositions, sometimes nullifying themselves as they submit to their will. An example of this is the refusal of partners to use condoms in sexual relationships, making women vulnerable to the acquisition of sexually transmitted infections (STIs), according to Jasmine. Corroborating the findings, studies argue that barriers to condom use in sexual relationships are related to gender inequality, which creates difficulties for women to negotiate their use and therefore they are exposed not only to HIV/STI, but also to unplanned pregnancy. ${ }^{11}$ Other research that also addresses the issue of women's difficulty in talking with spouses and vulnerability to STIs also points to cases of recidivism. ${ }^{12}$ Thus, in the diagnosis of STI, it is important that the professionals investigate the domestic context and, in case marital violence is identified, they should discuss strategies to sensitize women in terms of the importance of condom use to their health and to empower them to break with violence.

In addition to STIs, whose association with marital violence should be investigated by health professionals, the study points to the veiled nature of clinical complaints somatized as a result of such experience. Nausea, dizziness, weight loss, high blood pressure and depressive symptoms were clinical aspects unveiled in our study, which suggest for somatization of the experience of violence, regardless of its form of expression. Other studies confirm the relationship between coexistence with violent partners and commitment to physical and mental health, expressed through somatized clinical symptoms. Although these studies evidenced headache as the most commonly reported symptom, anxiety, low self-esteem, fear and lack of concentration were also observed, ${ }^{13}$ symptoms that were also mentioned in our study, as in the example of Sunflower, who expresses deep sadness and inattention, making her vulnerable.

Many studies corroborate that the somatization of a violent event is related to the development of depression, phobia, posttraumatic stress and suicide. ${ }^{14}$ The female mental health impairment is also observed in a study carried out in Spain, which found that women victims of violence, when compared to those who are not, experience more psychiatric consultations due to emotional disturbances and they tend to attempt suicide. ${ }^{15}$ It should be noted that these depressive symptoms may end up generating post-traumatic stress disorder (PTSD). One of the health problems most associated with violence victimization, social isolation, is one of the signs of PTSD. ${ }^{16}$

As to isolation, the study signals that some women have their freedom curtailed when they are embedded in a marital relationship permeated by violence. This situation ends up distancing them from family and social life, a situation that compromises the ability to establish interpersonal ties. This finding is consistent with research conducted in the United States, which argues that experiencing violent relationships affect relationships with others, because in a domestic relationship permeated by violence, the partner tends to control all aspects of the woman's life, thus separating her from her parents, siblings and the whole family, in addition to prohibiting her from working. ${ }^{17}$

With regard to the implications of violence for the professional life of women, the study reveals the feminine annulment, often by prohibition of the man, to the detriment of the dedication to the domestic tasks, situation that ends up compromising the opportunities to qualify for the work market. Women who drop out of study and work because of marriage and maternity move away from the labor market; thus, they become increasingly dependent on their partners and marital relationship..$^{18}$ When they decide on the separation, these women need to enter the labor market, but realize that they are not qualified. Therefore, it can be seen that exclusive dedication to the family, especially to meet the other's desire, and/or social isolation, hinders human development, understood as the capacity of the individual to achieve opportunities to be what they wish to be. ${ }^{19}$ Commitment to opportunities can occur in a number of areas, with a predominance of education and employment. ${ }^{20}$ It is important to mention that, when women enter the professional market, besides guaranteeing their livelihood as well as that of their children, they rescue their social identity, altered by constant aggressions, which also led them to social isolation. ${ }^{21}$

The repercussions of experiencing violence against women are added to the implications for their children, as they not only witness violence, but are also more vulnerable to violence, including situations in which they engage in times of conflict between parents. People who have witnessed violence perpetrated against their mothers domestically and/or suffered physical violence committed by their parents tend to experience violence in adulthood. ${ }^{20}$ Data on violence against women show that in over $65 \%$ of cases, children witness aggressions against their mothers and around $20 \%$ are also violated1. In the international scenario, research that indicates the high rate of intra-family violence among adolescents, argues that witnessing and/or experiencing violence in their homes increases their chances of developing behavioral problems and even depressive symptoms..$^{22}$ Aggressive and introspective behavior and emotional problems such as fear and depression were also uncovered in our study. 
In addition to the commitment on mental health, a study carried out in São Paulo, Brazil, reveals that experiences of violence in the family nucleus potentiate adolescents' vulnerability to social problems, such as drug abuse.$^{23} \mathrm{~A}$ study carried out with 881 adolescents in Mexico points out the relation between alcohol consumption and other drugs by adolescents in situations of violence. ${ }^{24}$ It is emphasized that adolescent drug use is seen as an "exit" from the experience of violent acts, increasing the possibility of consuming other psychoactive substances.

The experience of violence also interferes in the children's performance at school, mainly due to the recurrent memories of violent acts. Thus, adolescents have difficulties concentrating during classes, compromising such performance. In Philadelphia, Pennsylvania, 498 adolescents agree that exposure to violence triggers consequences such as learning disability and poor results at school, and also points to association with aggressive behavior, social isolation, lack of motivation, anxiety, and depression. ${ }^{25}$

Given the way in which violence affects the health and human development of children, women's mental illness is intensified when they feel guilty for exposing their children to domestic violence..$^{10}$ All this context of violence and emotional suffering indicates the need for health professionals to be prepared to recognize the problem, to welcome the women and to guide them appropriately to the services that meet their demands. The support of services is essential for the empowerment of women, not only to cease violence, but above all to encourage them to develop their potential and make their own choices. ${ }^{18}$

\section{FINAL CONSIDERATIONS}

The study points to marital violence in relation to the physical and mental health of women and their children. It is expressed by visible marks, such as bruises and cuts, and more veiled signs triggered by the process of somatization of the experience, such as dizziness, high blood pressure, low self-esteem, deep sadness, fear and depression. These repercussions lead us to the need for spaces in health that promote care to clinical issues, and it is essential to guarantee continuous care for emotional demands, since, although they are more difficult to be overcome, they are essential for overcoming somatized physical and mental illness.

Therefore, it is possible to realize that ensuring care for people in situations of domestic violence goes beyond the field of health. This is because the experience of violence for social relations was also pointed out as a repercussion of the phenomenon, both for women and for children. For children and adolescents, schools, including the Programa Saúde na Escola (PSE - School Health Program), should be alert for signs that suggest family conflict such as: aggressiveness, introspection, poor school performance and drug use. In the case of women, it is fundamental that health professionals seek to know their domestic contexts, because when they are in a situation of violence, they become more vulnerable to social isolation and annulment in the professional sphere. Such situations point to the need for psychological support in order to empower women to exercise mastery over their lives. In the social sphere, in the face of the spouse's financial dependence, qualification for the labor market and opportunities for income and employment are essential, so that they can also be economically empowered to leave the relationship of violence.

Considering that the experience of violence, at a preventive level, impairs the full development of the potential of people, thus limiting their personal and professional achievements, urges educational actions based on a gender perspective that allow the understanding that domestic violence is anchored in an uneven construction between men and women, socially shared. Therefore, the objective is to promote spaces for reflection so that children and adolescents, as well as adult men and women, can reflect on the implications of gender violence.

In view of the repercussions of the experience of domestic violence for women and children, the relevance of primary health care (PHC), recommended as a computer for the Sistema Único de Saúde (SUS - Unified Health System), stands out. Responsible for the orientation and coordination of health care networks, PHC, more precisely, the Family Health Strategy (FHS) could provide care for women in situations of domestic violence. This is because the FHS favors the recognition of cases, either during consultations, home visits and/or health education actions, as well as referrals. These demand by articulation of services of the different areas: health, education, social, legal, police, etc. To this end, a management that prioritises the (re) organization of services to ensure that people with a history of violence is actually assisted in their demands is essential, which transcends technical assistance to visible and punctual and/or fragmented emotional demands, especially when it comes to post-traumatic stress.

\section{REFERENCES}

1. Ministério da Saúde (BR). Secretaria de Políticas para as Mulheres. Balanço central de atendimento à Mulher. Brasília (DF): Ministério da Saúde; 2010.

2. Office on Women's Health. Violence Against Women. Washington: Department of Health and Human Service; 2015. p. 10-8.

3. Public Health Agency of Canada. Harper Government Invests in Community Projects across Canada to Support Victims of Violence. Toronto: Canada Newswire; 2015. p. 33-9.

4. Welsh Women's Aid. Office for National Statistics. The Crime Survey for England and Wales 2013/14, Polit. Stud: Ministery of Justice;2015. p. 12-68.

5. Lei $\mathrm{n}^{\circ}$ 11.340, de 7 de agosto de 2006 (BR). [Internet]. Brasil; 2006 [cited 2017 Jul 24]. Available from: http://www.planalto.gov.br/ ccivil_03/_ato2004-2006/2006/lei/l11340.htm

6. Strauss A, Corbin J. Pesquisa qualitativa: técnicas e procedimentos para o desenvolvimento de teoria fundamentada. Porto Alegre: Artmed, 2008.

7. Dantas CC, Leite JL, Lima SBS, Stipp MAC. Grounded theory - conceptual and operational aspects: a method possible to be applied in nursing research. Rev Latino-Am Enfermagem [Internet]. $2009 \mathrm{Jul} / \mathrm{Aug}$; [cited $2016 \mathrm{Dec} 3$ ]; 17(4):573-9. Available from: http://www.scielo.br/scielo.php?script=sci_arttext\&pid=S0104$11692009000400021 \&$ Ing=en. http://dx.doi.org/10.1590/S010411692009000400021 
8. Farchi S, Polo A, Asole S, Ruggieri MP, Di Lallo D. Use of emergency department services by women victims of violence in Lazio region, Italy. BMC Womens Health [Internet]. 2013 Jul; [cited 2016 Dec 3] 13:31. Available from: http://bmcwomenshealth.biomedcentral.com/ articles/10.1186/1472-6874-13-31. DOI: 10.1186/1472-6874-13-31

9. Cecílio LPP, Garbin CAS, Rovida TAS, Queiróz APDG, Garbin AJl. Violência interpessoal: estudo descritivo dos casos não fatais atendidos em uma unidade de urgência e emergência referência de sete municípios do estado de São Paulo, Brasil, 2008 a 2010. Epidemiol Serv Saúde [Internet]. 2012 Jun; [cited 2016 Dec 3]; 21(2):293-304. Available from: http://scielo.iec.pa.gov.br/scielo.php?script=sci arttext\&pid=S1679-49742012000200012\&Ing=pt. http://dx.doi. org/10.5123/S1679-49742012000200012

10. Dourado SM, Noronha CV. A face marcada: as múltiplas implicações da vitimização feminina nas relações amorosas. Physis [Internet].2014; [cited 2016 Dec 3]; 24(2):623-43. Available from: http://www.scielo.br/scielo. php?script=sci_arttext\&pid=S0103-73312014000200623\&lng=en . http://dx.doi.org/10.1590/S0103-73312014000200016

11. Sousa LB, Cunha DFF, Ximenes LB, Pinheiro AKB, Vieira NFC Conhecimentos, atitudes e prática de mulheres acerca do uso do preservativo. Rev Enferm UERJ [Internet]. 2011 Jan/Mar; [cited 2016 Dec 3]; 19(1):147-52. Available from: http://www.facenf.uerj.br/v19n1/ v19n1a24.pdf

12. Araújo DS, Morais HCT, Lins CS, Franco ES, Lucio IML, Falcão LMN. Práticas de sexo seguro e prevenção de DST/AIDS: conhecimento de jovens recém-ingressos em uma instituição de ensino superior. Rev Enferm UFPI [Internet]. 2012 Jan/Apr; [cited 2016 Dec 3]; 1(1):5663. Available from: http://www.ojs.ufpi.br/index.php/reufpi/article/ viewFile/710/624

13. Gomes N, Erdmann AL, Higashi GDC, Cunha KS, Mota RS, Diniz NMF. Preparo de enfermeiros e médicos para o cuidado à mulher em situação de violência conjugal. Rev Baiana Enferm [Internet]. 2012 Sep/Dec; [cited 2016 Dec 3]; 26(3):593-603. Available from: https:// portalseer.ufba.br/index.php/enfermagem/article/view/6754. http:// dx.doi.org/10.18471/rbe.v26i3.6754

14. Gadoni-Costa LM, Zucatti APN, Dell'Aglio DD. Violência contra a mulher: levantamento dos casos atendidos no setor de psicologia de uma delegacia para a mulher. Estud Psicol [Internet]. 2011 Apr/Jun; [cited 2016 Dec 3]; 28(2):219-27. Available from: http://www.scielo. br/scielo.php?script=sci arttext\&pid=S0103-166X2011000200009\& Ing=en\&nrm=iso. ISSN 1982-0275. http://dx.doi.org/10.1590/S0103$166 \times 2011000200009$

15. Martín-Baena D, Montero-Piñar I, Escribà-Agüir V, Vives-Cases C. Violence against young women attending primary care services in Spain: prevalence and health consequences. Fam Pract [Internet]. 2015 Aug; [cited 2016 Dec 3]; 32(4):381-6. Available from: https://www.ncbi.nlm. nih.gov/pubmed/25977133. DOI: 10.1093/fampra/cmv017

16. Gomes NP, Erdmann AL. Conjugal violence in the perspective of "Family Health Strategy" professionals: a public health problem and the need to provide care for the women. Rev Latino-Am Enfermagem [Internet]. 2014 Jan/Feb; [cited 2016 Dec 3]; 22(1):76-84. Available from: http://www.scielo.br/scielo.php?script=sci_arttext\&pid=S010411692014000100076\&lng=en. http://dx.doi.org/10.1590/01041169.3062.2397

17. Burnette $C E$, Cannon C. "It will always continue unless we can change something": consequences of intimate partner violence for indigenous women, children, and families. Eur J Psychotraumatol [Internet]. 2014 Sep; [cited 2016 Dec 3]; 5. Available from: https://www.ncbi.nlm.nih.gov/ pubmed/25279104. DOI: 10.3402/ejpt.v5.24585

18. Santos YG. Family, work and religion of women in social programs at São Paulo. Cad Pesqui [Internet]. 2014 Apr/Jun; [cited 2016 Dec 3]; 44(152):400-21. Available from: http://www.scielo.br/scielo. php?script=sci_arttext\&pid=S0100-15742014000200009\&lng=en\&nr m=iso. http://dx.doi.org/10.1590/198053142879

19. Programa das Nações Unidas Para o Desenvolvimento (PNUD). Desenvolvimento humano e IDH. Brasília: Organização das Nações Unidas; 2012. p. 20-33.

20. Miranda MPM, Paula CS, Bordin IA. Violência conjugal física contra a mulher na vida: prevalência e impacto imediato na saúde, trabalho e família. Rev Panam Salud Publica [Internet]. 2010 Apr; [cited 2016 Dec 3]; 27(4):300-8. Available from: http://www.scielosp.org/scielo. php?script=sci_arttext\&pid=S1020-49892010000400009. http://dx.doi. org/10.1590/S1020-49892010000400009

21. Wathen C, Nadine M, Jennifer CD, MacQuarrie BJ. The Impact of Domestic Violence in the Workplace: Results From a Pan-Canadian Survey. J Occup Environ Med [Internet]. 2015 Jul; [cited 2016 Dec 3]; 57(7):e65-71. Available from: http://journals.Iww.com/joem/ fulltext/2015/07000/The_Impact_of_Domestic_Violence_in_the_ Workplace_.19.aspx. DOI: 10.1097/JOM.0000000000000499

22. Yi S, Poudel KC, Yasuoka J, Yi S, Palmer PH, Jimba M. Exposure to violence in relation to depressive symptoms among male and female adolescent students in Cambodia. Soc Psychiatry Psychiatr Epidemiol [Internet]. 2013 Mar; [cited 2016 Dec 3]; 48(3):397-405. Available from: https://www.ncbi. nlm.nih.gov/pubmed/22820619. DOI: 10.1007/s00127-012-0553-2

23. Miura PO, Passarini GM, Ferreira LS, Paixão RA, Tardivo LS, Barrientos DMS. Cumulative Vulnerability: A Case Study on intrafamilial violence, Drug Addiction and Adolescent Pregnancy. Rev Esc Enferm USP [Internet]. 2014 Dec; [cited 2016 Dec 3]; 48(spe2):53-8. Available from: http://www.scielo.br/scielo.php?script=sci_arttext\&pid=S008062342014000800053\&lng=en\&nrm=iso. ISSN 0080-6234. http://dx.doi. org/10.1590/S0080-623420140000800009

24. Peinado J, Theresa Villanos M, Singh N, Leiner M. The association between exposure to violence, alcohol, and drugs and psychosocial and behavioral outcomes among Mexican-American adolescents of low socioeconomic status. Adicciones [Internet]. 2014; [cited 2016 Dec 3]; 26(1):27-33. Available from: https://www.ncbi.nlm.nih.gov/ pubmed/24652396

25. Lepore SJ, Kliewer W. Violence exposure, sleep disturbance, and poor academic performance in middle school. J Abnorm Child Psych [Internet]. $2013 \mathrm{Nov}$; [cited $2016 \mathrm{Dec}$ 3]; 41(8):1179-89. Available from: https://www.ncbi.nlm.nih.gov/pubmed/23315234.DOI:10.1007/s10802013-9709-0 